\title{
Influence of Breastfeeding and Deleterious Oral Habits in Malocclusions in Children
}

\author{
Fernanda Matias De Carvalho1,*, Lídia Audrey Rocha Valadas', Joseph Anderson Sá Nogueira', Paulo César Almeida², Patrícia Leal Dantas \\ Lobo ${ }^{1}$, Fernanda Leal Dantas Sales Pimentel ${ }^{2}$, Marina Sena Lopes da Silva Sacchetto ${ }^{3}$, Pollyanna Bitu De Aquino ${ }^{4}$ \\ 'Dentistry and Nursing School, Federal University of Ceara, Fortaleza-CE-BRAZIL. \\ 2State University of Ceara, Fortaleza-CE, BRAZIL. \\ ${ }^{3}$ Federal University of Piauí, Teresina-PI-BRAZIL. \\ ${ }^{4}$ Dentistry School, Christus University, Fortaleza-CE, BRAZIL.
}

\begin{abstract}
Introduction: Malocclusion is a pathology which has caused by multifactorial factores, being related to a lot of factors, as breastfeeding and deleterious oral habits. Objectives: The objective of this work was to verify the prevalence and association between time and type of breastfeeding with the installation of deleterious oral habits and consequential malocclusions. Materials and Methods: This is a transversal-type, observational, descriptive study, which evaluated 297 children, aged from three to five years, enrolled in municipal kindergartens. The first phase was carried out with a form directed to parents and guardians and collected information on the lactation period, presence of deleterious oral habits $(\mathrm{DOH})$ and socioeconomic data. The second step consisted of the clinical occlusal examination of children whose parents or guardian had signed the Informed Consent Form and that were within the inclusion criteria of the survey. The data analysis was conducted at a level of significance of $5 \%$ through the tests $\chi 2$ and odds ratio, the OddsRatio were determined by formula OR $=\mathrm{ad} / \mathrm{bc}$, both processed in the software SPSS version 14.0 Results: Deleterious oral habits had a prevalence of $96.6 \%$ in the sample,
\end{abstract}

the average time of exclusive breastfeeding was 4.57 months. The habit of highest incidence was the bottle suction, present in $69 \%$ of children, but the pacifier was the main responsible for developing malocclusions. Conclusion: The obtained data allow concluding that the breastfeeding time influenced directly the presence of deleterious oral habits and malocclusions in the primary dentition, and that digital sucking habits, pacifier sucking and baby's bottle are associated with malocclusions in the studied population.

Key words: Breastfeeding, Children, Habits, Malocclusion, Oral Health.

Correspondence

Dr. Fernanda Matias De Carvalho

Pharmacy Dentistry and Nursing School, Federal University of Ceara-1210, Capitão Francisco Pedro Street, Fortaleza-60430372, CE, BRAZIL.

Email: primoimplanto@gmail.com

DOI: 10.5530/jyp.2021.13.35

\section{INTRODUCTION}

Malocclusion is a pathology which has a multifactorial cause, being related to a lot of factors as genetic, lifestyle, diet, posture, among other causes that can have a great and growing influence. Due to the high prevalence of malocclusion, especially in children, the World Health Organization (WHO) began to consider it the third biggest oral health problem. ${ }^{1,2}$

Breastfeeding is essential for the baby's development, being recommended as an exclusive nutrition until the sixth month of life. The exclusive natural breastfeeding will positively influence the development of the stomatognathic system, allowing an adequate suction, as well as the correct position of the tongue and lips, synchronizing swallowing and breathing. During breastfeeding, several muscles are moved, such as masseter, lateral and medial pterygoid, temporal, digastric, mylohyoid muscle, buccinator muscles, influencing the craniofacial growth. ${ }^{3}$ In addition, exclusive breastfeeding decreases future oral habits and prevents malocclusion. ${ }^{1}$

Deleterious oral habits result from the repetition of acts with certain purposes, and its consequence will depend on its frequency, duration and intensity. The habit is initially aware, but, throughout time, it becomes automatic, frequent and unconscious, increasingly becoming resistant to change. These habits are very common in both genders, especially in childhood, due to the digital sucking and use of pacifiers and baby's bottles, and may cause changes in the stomatognathic system, distorting the dentition and altering the facial morphology. ${ }^{1,4}$

Nasal breathing, chewing and swallowing are physiological habits, however, use of pacifiers, baby's bottles, mouth breathing, onychophagy, bruxism, are considered para-functional habits. The last ones, when installed and throughout time, can cause changes in the stomatognathic system and cause facial imbalance, producing artificial muscular forces that can cause tooth and bone deformation, by modifying the position of the teeth. ${ }^{4,5}$

Consequently, an unbalanced swallowing emerges, which can result in a malocclusion even when the habit is removed. Several studies show an inverse relationship between duration of breastfeeding and the presence of deleterious oral habits, in which children with shorter duration of exclusive breastfeeding have more chances of acquiring deleterious oral habits when compared to children who were exclusively breastfed. ${ }^{5,6}$

The main consequences associated with these habits, especially when persisting after the age of three years, are changes in the hard palate, bad dental occlusions, changes in mobility of tongue and lips, in addition to other direct and indirect changes in the perioral musculature and psychological problems. . $^{1,7}$

The knowledge of the functioning of the maxillomandibular complex and understanding the disorders caused by malocclusion is extremely 
important for all Dentistry areas, especially orthodontists, pedodontists, as well as general practitioners of primary care network. ${ }^{8}$ In this way, knowing the consequences caused by these habits is of fundamental importance for promoting children's health, because the earlier it is detected and corrected, the greater the possibility of correction of malocclusion. ${ }^{9}$

Studies with preschool children, especially in children aged three years old, reported a high prevalence of malocclusion in both genders caused by deleterious oral habits. The main problems reported are the open bite, crossbite and accentuated overjet. ${ }^{1,10}$

\section{MATERIALS AND METHODS}

\section{Type of Study and Site}

This is a quantitative, observational and descriptive study, approval by Ethics Committee, carried out in two phases. After signed the informed consent form, the parents/guardians answered the first phase, based on a validated questionnaire applied for them, aimed at obtaining retrospective information about time and manner of breastfeeding and harmful oral habits. The second phase was performed in the municipal day care centers and consisted in the clinical-buccal examination of children with the aim in order to assess the existence of malocclusion.

The study population consisted of children enrolled at all public schools of Carnaubal, a municipality located in the state of Ceara, in Northeastern Brazil. The population of children aged between zero and six years old is estimated at 2,526, with 725 children aged three through five years enrolled in municipal day care centers (Brazilian Institute of Geography and Statistics).

\section{Sample Description}

The study population consisted of 725 children enrolled in the municipal day care centers of Carnaubal-CE. This value applied in the formula below, indicated for finite populations $(\mathrm{N}=725)$, provided a sample size "n" equal to 279 children.

$$
n=\frac{\mathrm{t}^{2}{ }_{5 \%} \times \mathrm{P} \times \mathrm{Q} \times \mathrm{N}}{\mathrm{e}^{2}(\mathrm{~N}-1)+\mathrm{t}^{2}{ }_{5 \%} \times \mathrm{P} \times \mathrm{Q}}
$$

\section{Inclusion and Exclusion Criteria}

The study included children enrolled in the public-school network, aged between three and five years old and who had complete primary dentition.

The study excluded children eith extensive cavities or large coronary destruction that could lead to interference in occlusal relationships, who were undergoing or had undergone orthodontic intervention, with dental anomalies.

\section{Data Collection}

\section{First phase: application of questionnaires}

The parents or guardians were contacted to attend this research. The questionnaire aimed to search information on the period and type of breastfeeding, as well as the existence of deleterious oral habits.

\section{Second phase: clinical-buccal examination}

The children underwent oral examination conducted by visual inspection in the day care centers, by a single examiner properly calibrated, with intra-examiner reliability (kappa 0.98) under natural lighting, at intervals of approximately three minutes for each exam. The materials used in the exam were spatula, pencil and millimeter ruler.

\section{Assessed Aspects}

The evaluation of the morphological aspects of the occlusion obeyed the concept of normality for the primary dentition suggested by Martins ${ }^{8}$ and Silva Filho et al. ${ }^{11}$ who adapted the permanent denture occlusal references for this stage of development. Thus, the criteria used to define normal occlusion in the primary dentition were: transversal compatibility between the dental arches; sagittal relationship between the dental arches determined by the relation of canines; relationship of incisors keeping positive vertical and horizontal trespass; presence or absence of the inter-incisors diastemas and spaces primates; absence of impactions.

The following indicators of malocclusion were evaluated with the occlusion in position of maximum usual intercuspation (MUI): crosssectional relationship (posterior crossbite), canine relationship (Class I, II or III), horizontal trespass (normal overjet, anterior crossbite), normal vertical trespass, overbite, open bite and labial seal (absent, present).

\section{Statistical Analysis}

The association analyses were performed by means of non-parametric tests of $\chi^{2}$ and likelihood ratio. The inferential analyses whose $\mathrm{p}$-values were less than 0.05 were considered statistically significant. Data were processed in software SPSS version 14.0. The calculation of odds ratios was performed with a confidence interval (CI) of $95 \%$. OR= ad/bc

\section{RESULTS}

Seven schools of the municipality were randomly selected, totalling 406 children; of these, 47 were excluded because their parents did not attend the meetings to answer the questionnaire or did not return it. Other 62 children were excluded because they did not meet the inclusion criteria mentioned in the methodology. Thus, the final sample consisted of 297 children.

In the studied population ( $n=297), 55.6 \%$ of the children $(n=165)$ were male and $44.4 \%(n=132)$ were female. Students enrolled in pre-school participated in the survey, with the following distribution regarding age range: three years $(n=83)$, four years $(n=115)$ and five years $(n=99)$.

The questionnaire applied to the children's parents and guardians was, in their majority (86.6\%), answered by mothers. Regarding socioeconomic data of the child's parents/guardians and family, we obtained the profile described below. In relation to family income, $34.4 \%$ had no income and the majority, $56.4 \%$, had an income of up to one minimum wage; many reported that the source of income consisted of the Bolsa Família Program (an assistance granted by the Federal Government).

Regarding the type of breastfeeding, $63.3 \%$ of the sample $(n=188)$ received mixed breastfeeding (natural and artificial with baby bottles), $30 \%(n=89)$ breastfeeding and $6.7 \%(n=20)$ used artificial breastfeeding. As for breastfeeding, the results show that this occurred during a mean of 4.57 months \pm standard deviation (SD) of 2.21 .

The average number of habits per child was $2.74 \pm$ SD of 1.36 habits. Only 13 children (4.4\%) did not present any type of deleterious oral habits, while the other $96.6 \%$ had at least one DOH (Table 1).

When comparing the influence of the duration of exclusive breastfeeding to the different malocclusions surveyed, this association was only significant in relation to the horizontal and vertical trespass, $p=0.02$ and $p=0.027$, respectively. Thus, a higher exclusive breastfeeding (EBF) duration resulted in no change in the horizontal (78\%) and vertical trespass $(76.2 \%)$. However, a shorter EBF duration resulted in the development of overjet (27.2\%) and open bite (19.2\%) (Table 2).

In relation to the duration of natural breastfeeding in months and the development of $\mathrm{DOH}$, there was a significant relationship with the habits of the baby's bottle, pacifier and finger sucking (Table 3 ). 
Among the children without deleterious oral habits, $69.2 \%$ had been breastfed for a period equal to, or higher than, 13 months. All children breastfed for less than six months developed some type of DOH (Table 4).

In relation of the presence or absence of malocclusions influenced by maternal breastfeeding in months, $56 \%$ of the children who were breastfed for 13 months or more have not presented malocclusions, while $63 \%$ of those that received natural maternal breastfeeding for less than six months have developed some type of malocclusion (Table 5).

According to Table 6 the relationship between the presence of a $\mathrm{DOH}$ and the development of malocclusion was significant only for the pacifier sucking habit, which showed that $64.8 \%$ of the sample that have used it developed some type of malocclusion.

Table 1: Frequency of harmful oral habits in the sample.

\begin{tabular}{ccc}
\hline DOH Numbers & Frequency & $\%$ \\
\hline 0 & 13 & 4,4 \\
1 & 40 & 13,5 \\
2 & 79 & 26,6 \\
3 & 82 & 27,6 \\
4 & 50 & 16,8 \\
5 & 28 & 9,4 \\
6 & 4 & 1,3 \\
7 & 1 & 0,3 \\
TOTAL & 297 & 100 \\
\hline
\end{tabular}

Table 2: Relationship between labial sealing, malocclusions and exclusive breatfeeding duration in months.

\begin{tabular}{|c|c|c|c|c|c|}
\hline & \multicolumn{5}{|c|}{$\begin{array}{c}\text { Exclusive } \\
\text { Breastfeeding }\end{array}$} \\
\hline & & $0-5$ & 6 or + & Total & $P$ \\
\hline \multirow{4}{*}{$\begin{array}{l}\text { Labial } \\
\text { Sealing }\end{array}$} & \multirow{2}{*}{ Absent } & 13 & 9 & 22 & \multirow{4}{*}{$>0.05$} \\
\hline & & $10.4 \%$ & $5.4 \%$ & $7.5 \%$ & \\
\hline & \multirow{2}{*}{ Present } & 112 & 159 & 271 & \\
\hline & & $89.6 \%$ & $94.6 \%$ & $92.5 \%$ & \\
\hline \multirow{6}{*}{$\begin{array}{l}\text { Posterior } \\
\text { Crossbite }\end{array}$} & \multirow{2}{*}{ Absent } & 113 & 157 & 270 & \multirow{6}{*}{$>0.05$} \\
\hline & & $90.4 \%$ & $93.5 \%$ & $92.2 \%$ & \\
\hline & \multirow{2}{*}{ Unilateral } & 9 & 10 & 19 & \\
\hline & & $7.2 \%$ & $6 \%$ & $6.5 \%$ & \\
\hline & \multirow{2}{*}{ Bilateral } & 3 & 1 & 4 & \\
\hline & & $2.4 \%$ & $0.6 \%$ & $1.4 \%$ & \\
\hline \multirow{6}{*}{$\begin{array}{l}\text { Horizontal } \\
\text { Trespass }\end{array}$} & \multirow{2}{*}{ Normal } & 79 & 131 & 210 & \multirow{6}{*}{0.020} \\
\hline & & $63.3 \%$ & $78 \%$ & $71.7 \%$ & \\
\hline & \multirow{2}{*}{ Overjet } & 34 & 26 & 60 & \\
\hline & & $27.2 \%$ & $15.5 \%$ & $20.5 \%$ & \\
\hline & \multirow{2}{*}{$\begin{array}{l}\text { Anterior } \\
\text { Crossbite }\end{array}$} & 12 & 11 & 23 & \\
\hline & & $9.6 \%$ & $6.5 \%$ & $7.8 \%$ & \\
\hline \multirow{6}{*}{$\begin{array}{l}\text { Vertical } \\
\text { Trespass }\end{array}$} & \multirow{2}{*}{ Normal } & 84 & 128 & 212 & \multirow{6}{*}{0.027} \\
\hline & & $67.2 \%$ & $76.2 \%$ & $72.4 \%$ & \\
\hline & \multirow{2}{*}{ Overbite } & 17 & 26 & 43 & \\
\hline & & $13.6 \%$ & $15.5 \%$ & $14.7 \%$ & \\
\hline & \multirow{2}{*}{ Open bite } & 24 & 14 & 38 & \\
\hline & & $19.2 \%$ & $8.3 \%$ & $12.9 \%$ & \\
\hline
\end{tabular}

\begin{tabular}{|c|c|c|c|c|c|c|c|c|c|c|}
\hline & & & & \multicolumn{7}{|c|}{ Maternal breastfeeding (months) } \\
\hline & & \multicolumn{2}{|c|}{$0-5$} & \multicolumn{2}{|c|}{$6-12$} & \multicolumn{2}{|c|}{13 or more } & \multicolumn{2}{|c|}{ TOTAL } & \multirow[b]{2}{*}{$\mathbf{p}$} \\
\hline & & n & $\%$ & $\mathrm{n}$ & $\%$ & n & $\%$ & n & $\%$ & \\
\hline \multirow[b]{2}{*}{ Baby's bottle } & S & 62 & 92.5 & 60 & 78.9 & 83 & 54.2 & 205 & 69.3 & \multirow[b]{2}{*}{$<0.0001$} \\
\hline & $\mathrm{N}$ & 5 & 7.5 & 16 & 21.1 & 70 & 45.8 & 91 & 30.7 & \\
\hline \multirow{3}{*}{ Pacifier } & S & 47 & 70.1 & 30 & 39.5 & 28 & 18.4 & 105 & 35.6 & \multirow{3}{*}{$<0.0001$} \\
\hline & & & & & & & & & & \\
\hline & $\mathrm{N}$ & 20 & 30 & 46 & 60.5 & 124 & 81.7 & 190 & 64.4 & \\
\hline \multirow{3}{*}{ Finger } & S & 8 & 11.9 & 9 & 12 & 4 & 2.6 & 21 & 7.1 & \multirow{3}{*}{0.008} \\
\hline & & & & & & & & & & \\
\hline & $\mathrm{N}$ & 59 & 88.1 & 66 & 88 & 148 & 97.4 & 273 & 92.9 & \\
\hline \multirow{2}{*}{ Onychophagy } & $S$ & 22 & 33.3 & 27 & 38.6 & 59 & 39.6 & 108 & 37.9 & \multirow{2}{*}{$>0.05$} \\
\hline & $\mathrm{N}$ & 44 & 66.7 & 43 & 61.4 & 90 & 60.4 & 177 & 62.1 & \\
\hline \multirow{2}{*}{ Biting Objects } & S & 26 & 39.4 & 36 & 50.7 & 78 & 51.7 & 140 & 48.6 & \multirow{2}{*}{$>0.05$} \\
\hline & $\mathrm{N}$ & 40 & 60.6 & 35 & 49.3 & 73 & 48.3 & 148 & 51.4 & \\
\hline \multirow{3}{*}{ Bruxism } & S & 19 & 29.2 & 27 & 38 & 60 & 41.1 & 106 & 37.6 & \multirow{3}{*}{$>0.05$} \\
\hline & & & & & & & & & & \\
\hline & $\mathrm{N}$ & 46 & 70.8 & 44 & 62 & 86 & 58.9 & 176 & 62.4 & \\
\hline \multirow{2}{*}{$\begin{array}{l}\text { Sleeping with mouth } \\
\text { breathing }\end{array}$} & $\mathrm{S}$ & 36 & 54.5 & 33 & 46.5 & 60 & 39.7 & 129 & 44.8 & \multirow{2}{*}{$>0.05$} \\
\hline & $\mathrm{N}$ & 30 & 45.5 & 38 & 53.5 & 91 & 60.3 & 159 & 55.2 & \\
\hline
\end{tabular}


Table 4: Relationship between labial sealing, malocclusions and time of maternal brestfeeding in months.

\begin{tabular}{|c|c|c|c|c|c|c|}
\hline & & \multicolumn{3}{|c|}{$\begin{array}{l}\text { Maternal Breastfeeding } \\
\text { (months) }\end{array}$} & \multirow[b]{2}{*}{ Total } & \multirow[b]{2}{*}{$P$} \\
\hline & & $0-5$ & 6-12 & $\begin{array}{c}13 \\
\text { or }+\end{array}$ & & \\
\hline \multirow{4}{*}{$\begin{array}{l}\text { Labial } \\
\text { Sealing }\end{array}$} & \multirow{2}{*}{ Absent } & 10 & 4 & 8 & 22 & \multirow{4}{*}{0.029} \\
\hline & & $14.9 \%$ & $5.3 \%$ & $5.2 \%$ & $7.4 \%$ & \\
\hline & \multirow{2}{*}{ Present } & 57 & 72 & 145 & 274 & \\
\hline & & $85.1 \%$ & $94.7 \%$ & $94.8 \%$ & $92.6 \%$ & \\
\hline \multirow{6}{*}{$\begin{array}{l}\text { Posterior } \\
\text { Crossbite }\end{array}$} & \multirow{2}{*}{ Absent } & 56 & 69 & 148 & 273 & \multirow{6}{*}{0.009} \\
\hline & & $83.6 \%$ & $90.8 \%$ & $96.7 \%$ & $92.2 \%$ & \\
\hline & \multirow{2}{*}{ Unilateral } & 8 & 6 & 5 & 19 & \\
\hline & & $11.9 \%$ & $7.9 \%$ & $3.3 \%$ & $6.4 \%$ & \\
\hline & \multirow{2}{*}{ Bilateral } & 3 & 1 & 0 & 4 & \\
\hline & & $4.5 \%$ & $1.3 \%$ & $0 \%$ & $1.4 \%$ & \\
\hline \multirow{6}{*}{$\begin{array}{l}\text { Horizontal } \\
\text { Trespass }\end{array}$} & \multirow{2}{*}{ Normal } & 34 & 50 & 128 & 212 & \multirow{6}{*}{$\begin{array}{c}< \\
0.0001\end{array}$} \\
\hline & & $50.7 \%$ & $65.8 \%$ & $83.7 \%$ & $71.6 \%$ & \\
\hline & \multirow{2}{*}{ Overjet } & 25 & 20 & 15 & 60 & \\
\hline & & $37.3 \%$ & $26.3 \%$ & $9.8 \%$ & $20.3 \%$ & \\
\hline & \multirow{2}{*}{$\begin{array}{l}\text { Anterior } \\
\text { Crossbite }\end{array}$} & 8 & 6 & 10 & 24 & \\
\hline & & $11.9 \%$ & $7.9 \%$ & $6.5 \%$ & $8.1 \%$ & \\
\hline \multirow{6}{*}{$\begin{array}{l}\text { Vertical } \\
\text { Trespass }\end{array}$} & \multirow{2}{*}{ Normal } & 40 & 53 & 122 & 215 & \multirow{6}{*}{$\begin{array}{c}< \\
0.0001\end{array}$} \\
\hline & & $59.7 \%$ & $69.7 \%$ & $79.7 \%$ & $72.6 \%$ & \\
\hline & \multirow{2}{*}{ Overbite } & 8 & 10 & 25 & 43 & \\
\hline & & $11.9 \%$ & $13.2 \%$ & $16.3 \%$ & $14.5 \%$ & \\
\hline & \multirow{2}{*}{ Open bite } & 19 & 13 & 6 & 38 & \\
\hline & & $28.4 \%$ & $17.1 \%$ & $3.9 \%$ & $12.8 \%$ & \\
\hline
\end{tabular}

Table 5: Relationship between the presence of malocclusion and time of maternal breastfeeding in months.

\begin{tabular}{cccccccc}
\hline \multirow{2}{*}{$p=0.006$} & \multicolumn{9}{c}{ Malocclusion } \\
\hline & & Present & \multicolumn{2}{c}{ Absent } & \multicolumn{2}{c}{ Total } \\
\hline & $\mathbf{n}$ & $\%$ & $\mathbf{N}$ & $\%$ & $\mathbf{n}$ & $\%$ \\
\hline Maternal & $0-5$ & 42 & 63 & 25 & 37 & 67 & 100 \\
$\begin{array}{c}\text { Breastfeeding } \\
\text { (Months) }\end{array}$ & $6-12$ & 47 & 62 & 29 & 38 & 76 & 100 \\
& 13 or + & 67 & 44 & 86 & 56 & 153 & 100 \\
& Total & 156 & 53 & 140 & 47 & 296 & 100 \\
\hline
\end{tabular}

Children who presented the pacifier sucking habit were 2.15 times more likely to develop malocclusions than those that did not have this habit (Table 7).

\section{DISCUSSION}

The importance of exclusive breastfeeding during the first six months of life for children's health is scientifically evidenced in several aspects. In relation to exclusive breastfeeding, the results of this study showed that $168(56.6 \%)$ children were exclusively breastfed up to six months and the total mean of exclusive breastfeeding was 4.57 months; these data are still far from the target recommended by WHO, which is $100 \%$ of exclusive breastfeeding up to six months.
Table 6: Relationship between deleterious oral habits and the presence of malocclusion.

\begin{tabular}{|c|c|c|c|c|c|c|c|c|}
\hline \multicolumn{9}{|c|}{ Malocclusion } \\
\hline \multicolumn{2}{|c|}{ Present } & \multicolumn{2}{|c|}{ Absent } & \multicolumn{2}{|c|}{ Total } & \multirow[b]{2}{*}{$n$} & \multirow[b]{2}{*}{$\%$} & \multirow[b]{2}{*}{$p$} \\
\hline & & $n$ & $\%$ & $n$ & $\%$ & & & \\
\hline \multirow[t]{2}{*}{ Baby's Bottle } & Yes & 113 & 55 & 92 & 45 & 205 & 100 & $>0.05$ \\
\hline & No & 44 & 47.8 & 48 & 52.2 & 92 & 100 & \\
\hline \multirow[t]{2}{*}{ Pacifier } & Yes & 68 & 64.8 & 37 & 35.2 & 105 & 100 & 0.002 \\
\hline & No & 88 & 46 & 103 & 54 & 191 & 100 & \\
\hline \multirow[t]{2}{*}{ Finger } & Yes & 13 & 59 & 9 & 41 & 22 & 100 & $>0.05$ \\
\hline & No & 142 & 52 & 131 & 48 & 273 & 100 & \\
\hline \multirow[t]{2}{*}{ Onychophagy } & Yes & 56 & 52 & 52 & 48 & 108 & 100 & $>0.05$ \\
\hline & No & 92 & 51.7 & 86 & 48.3 & 178 & 100 & \\
\hline \multirow[t]{2}{*}{ Biting Objects } & Yes & 71 & 50.4 & 70 & 49.6 & 141 & 100 & $>0.05$ \\
\hline & No & 79 & 53.4 & 69 & 46.6 & 148 & 100 & \\
\hline \multirow[t]{2}{*}{ Bruxism } & Yes & 54 & 51 & 52 & 49 & 106 & 100 & $>0.05$ \\
\hline & No & 95 & 53.7 & 82 & 46.3 & 177 & 100 & \\
\hline \multirow{2}{*}{$\begin{array}{c}\text { Sleeping } \\
\text { with mouth } \\
\text { breathing }\end{array}$} & Yes & 69 & 53 & 61 & 47 & 130 & 100 & $>0.05$ \\
\hline & No & 83 & 52 & 76 & 48 & 159 & 100 & \\
\hline
\end{tabular}

Table 7: Estimate of the risk for developing malocclusion in children with different deleterious oral habits.

\begin{tabular}{ccc}
\hline DOH & OddsRatio & $95 \% \mathrm{Cl}$ \\
\hline Baby's Bottle & 1.34 & $0.81-2.19$ \\
Pacifier & 2.15 & $1.31-3.51$ \\
Finger & 1.33 & $0.55-3.22$ \\
Onychophagy & 1.00 & $0.62-1.62$ \\
Biting Objects & 0.88 & $0.55-1.40$ \\
Bruxism & 0.89 & $0.55-1.45$ \\
Mouth breathing sleep & 1.03 & $0.65-1.64$ \\
\hline
\end{tabular}

The type of predominant breastfeeding in this study was the mixed breastfeeding provided to $63.3 \%$ (188) of the children, followed by the exclusive breastfeeding, 30\% (89), and, finally, the artificial breastfeeding, which occurred in only $6.7 \%$ (20) of the sample, which are close to those obtained in the city of João Pessoa-PB, in a similar study, with pre-school children aged three through five years, in which mixed breastfeeding 
occurred in $72.7 \%$ of cases, $16.4 \%$ of the children received exclusive natural breastfeeding and $10.9 \%$ artificial feeding. ${ }^{12}$

Of the total (297) of the surveyed children, 96.6\% (284) developed, at least, one type of deleterious oral habit, without any prevalence regarding gender or age. This result was similar to a study conducted by Rochelle et al. ${ }^{13}$ in the state of São Paulo, which found a frequency of $95.6 \%$ of DOH. Cavalcanti et al. ${ }^{14}$ showed that $73.4 \%$ of the children examined in their study had at least one type of malocclusion; Mendes et al. ${ }^{12}$ found a prevalence of $64.1 \%$ of DOHs in the population, a possible explanation for this value is that this study only surveyed non-nutritious sucking habits, while the present study observed numerous other habits such as: onychophagy, biting objects, bruxism and mouth breathing.

The duration of exclusive breastfeeding significantly influenced the development of the baby's bottle and pacifier sucking habits $(p<0.010)$. Furthermore, children who were breastfed artificially were 3.5 times more likely to develop some type of malocclusion. As well as in the study performed by Carrascoza et al. ${ }^{15}$ who accompanied mothers and infants aged up to six months for 120 days in a breastfeeding program, showing a relationship between a greater use of pacifiers in children who were not subject to exclusive maternal breastfeeding.

The bivariate analysis between duration of breastfeeding and the existence of oral habits revealed that $69.2 \%$ of children who did not have DOH had been breastfed for more than one year, which is statistically significant, in accordance with the findings of Cavalcanti et al. ${ }^{14}$ that found that $65.7 \%$ of children without DOH had been breastfed for a period greater than or equal to 19 months.

The socioeconomic indicators education, residence, income did not influence the development of $\mathrm{DOH}$, similar to the study performed by Tomita et al. ${ }^{10}$ who evaluated the relationship between socioeconomic determinants and oral habits of risk for malocclusions in preschoolchildren in the city of Bauru-SP.

There was no statistically significant relationship for the habits of onychophagia, biting objects, bruxism and mouthe breathing sleep. A similar fact occurred in the association between duration of breastfeeding and the presence of malocclusion, because, the longer the breastfeeding duration, the greater the chances of developing labial sealing and normal occlusion; all items related to the posterior crossbite, horizontal and vertical trespass and labial sealing showed a $p$-value $<0.05$.

The mean number of habits per children was $2.74 \pm$ SD of 1.36 habits and may appear isolated or associated with other habits. The most frequent habit was the use of baby's bottle, present in $69 \%$ of the surveyed children, a value smaller than the one found by Rochelle et al. ${ }^{13}$ which was $93.2 \%$. The use of baby's bottle can increase 2.71 times the risk of children for developing accentuated overjet and 2.74 times the chance of developing anterior open bite. According to Cavalcanti et al. ${ }^{14}$ the early introduction of baby's bottle indicates a pattern of low impact on muscular activity and may interfere with the normal development of the alveolar edges and hard palate and consequently lead to malocclusion.

Onychophagy, bruxism and pacifier sucking were present in 38\%, 37.5\% and $35.5 \%$ of the sample, respectively. The prevalence of bruxism was similar to that found by Serra-Negra et al. ${ }^{16}$ in a study with 652 children in the city of Belo-Horizonte-MG, which was $35.3 \%$; in accordance with the aforementioned study, this study did not find the association between gender, age and presence of bruxism. There is a large discrepancy in the literature regarding the prevalence of bruxism: in Hong Kong, using polysomnography, there was a prevalence of $8.5 \%$ of the bruxism habit. ${ }^{17}$ In Brazil, Valera et al. ${ }^{18}$ based on parents' reports to assess the habit of nocturnal bruxism and observed that this habit was present in $43 \%$ of the children. In a study developed with American children, Cheifetz et al. ${ }^{19}$ also used parents' reports to assess the presence of nocturnal bruxism habit among schoolchildren and found that $38 \%$ of them had the habit.

As seen, the pacifier held the penultimate place in the index of the most frequent deleterious habits, with only $35.5 \%$. Nevertheledd, this result differs from numerous studies, such as de Sousa et al. ${ }^{20}$ Mendes et al. ${ }^{12}$ Serra-Negra et al. ${ }^{21}$ Cavalcanti et al.$^{14}$ which showed that the pacifier was the most common habit and affected, respectively: 50\%, 53.7\%, 75\% and $84.9 \%$ of children.

Digital sucking was the least prevalent habit, affecting only 22 children (7.5\%), in concordance with the study of Rochelle et al. ${ }^{13}$ which also showed it as the least frequent parafuncional habit: $8.6 \%$. Other researches, such as Serra-Negra et al. ${ }^{16}$ and Mendes et al. ${ }^{12}$ found, respectively, an impairment of $10 \%$ and $10.4 \%$ for this habit. When assessing the results of digital sucking in children's occlusion, its presence increases 3.63 times the risk of presenting accentuated overjet.

In this study, $53 \%$ of the sample presented at least one type of malocclusion in an average of $1,47 \pm 0.5$, with overjet as the most frequent, present in 60 children $(20.20 \%)$ of the sample. The lowest prevalence was the bilateral posterior crossbite that occurred in only $1.3 \%$. Tomita et al..$^{10}$ in a study developed in Bauru with children aged three through five years, found a similar prevalence of malocclusion, with $51.3 \%$ among boys and $56.9 \%$ among girls. They also observed that this prevalence was significantly higher in children aged three years, which differs from the present study, which showed no significant relationship between gender and age with the appearance of occlusopathies and DOH. Amary et al. ${ }^{22}$ state that if the habit occurs up to two years old, there should not be any concern, but all habit lasting more than three years or very frequent will be deleterious and can cause severe malocclusions. Cavalcanti et al. ${ }^{14}$ and Sousa et al. ${ }^{20}$ argue that the persistence of DOH in children above three years significantly increases the probability of developing a dental arch with undesirable deciduous dentition occlusal features.

\section{CONCLUSION}

According to the results described, and considering the surveyed sample, it was the duration of exclusive breastfeeding directly influence the presence of deleterious oral habits and consequent malocclusion in the deciduous dentition of children aged three through five years from the municipality of Carnaubal-CE. Moreover, mixed breastfeeding was the most favorable to developing $\mathrm{DOH}$ and occlusion normality deviations.

\section{ACKNOWLEDGEMENT}

We acknowledge the participants of the study.

\section{CONFLICT OF INTEREST}

The authors declare that there is no conflict of interest.

\section{ABBREVIATIONS}

CE: Brazil; CI: Confidence interval; DOH: Deleterious oral habits; EBF: Exclusive breastfeeding; MUI: Maximum usual intercuspation; SD: standard deviation; WHO: World Health Organization.

\section{REFERENCES}

1. Antunes LS, Teixeira EC, Gomes IF, Almeida MH, Mendes PP, Antunes LAA Avaliação da Relação Causal Entre a Presença de Hábitos Bucais Deletérios Tipo de Aleitamento e Maloclusões em Crianças na Dentadura Decídua. Unopar Cient Ciênc Biol Saúde. 2015;17(2):75-80.

2. Knösel M, Nüser C, Jung K, Helms HJ, Engelke W, Sandoval P. Interaction between deglutition, tongue posture, and malocclusion: A comparison of intraoral compartment formation in subjects with neutral occlusion or different types of malocclusion. The Angle Orthodontist. 2016;86(5):697-705.

3. Aguilar MC, Madrid NB, Baena LG, Mur NV, Guisado RB, Sánchez AL. Breastfeeding as a method to prevent cardiovascular diseases in the mother 
and the child. Nutricion hospitalaria: Organo oficial de la Sociedad Espanola de Nutricion Parenteral y Enteral. 2015;33(2):482-93.

4. Gisfrede TF, Kimura JS, Reyes A, Bassi J, Drugowick R, Matos R, et al. Hábitos bucais deletérios e suas consequências em Odontopediatria. Revista Brasileira de Odontologia. 2016;73(2):144-9.

5. Morales-Chávez MC, Vechio SDRM. Infuencia de la lactancia materna en la aparición de hábitos paraFuncionales y maloclusiones: Estudio transversal. Univ Odontol. 2014;33(71):19-28.

6. Miotto MHMB, Cavalcante WS, Godoy LM, Campos DMKS, Barcellos L. Anterior open bite prevalence associated with oral habits in 3-5 year old children from Vitória, ES. Rev CEFAC. 2014;16(4):1303-10.

7. Leite-Cavalcanti A, Medeiros-Bezerra PK, Moura C. Aleitamento natural, aleitamento artificial, hábitos de sucção e maloclusões em pré-escolares brasileiros. Revista de Salud Pública. 2007;9(2):194-204.

8. Martins JCR, Sinimbu CMB, Dinelli TCDS, Martins LP, Raveli DB. Prevalência de Má Oclusão em Pré-Escolares de Araraquara: Relação da Dentição Decídua com Hábitos e Nível Sócio Econômico. Revista Dental Press de Ortodontia e Ortopedia Facial. 1998;3(6):35-43.

9. Zapata M, Bachiega JC, Marangoni AF, Jeremias JE, Ferrari RA, Bussadori SK, et al. Ocorrência de mordida aberta anterior e hábitos bucais deletérios em crianças de 4 a 6 anos. Revista CEFAC. 2010;12(2):267-71.

10. Tomita NE, Bijella VT, Franco LJ. Relação entre hábitos bucais e má oclusão em pré-escolares. Rev Saúde Pública. 2000;34(3):299-303.

11. Filho SOG, Silva PRB, Rego MVNN, Silva FPL, Cavassan AO. Epidemiologia da má oclusão na dentadura decídua. Ortodontia. 2002;35(1):22-33.

12. Mendes ACR,Valença AMG, Lima CCM. Associação entre aleitamento, hábitos de sucção não-nutritivos e maloclusões em crianças de 3 a 5 anos. Cienc Odontol Bras. 2008;11(1):67-75.
13. Rochelle IMF, Tagliaferro EPS, Pereira AC, Meneghim MC, Nóbilo KA, Ambrosano GMB. Amamentação, hábitos bucais deletérios e oclusopatias em crianças de 5 anos de idade em São Pedro, SP. Dental Press J Orthod. 2010;15(2):71-81.

14. Cavalcanti AL, Bezerra PKM, Moura C. Aleitamento Natural, Aleitamento Artificial, Hábitos de Sucção e Maloclusões em Pré-escolares Brasileiros. Rev Salud Pública. . 2007;9(2):194-204.

15. Carrascoza KC, Possobon RF, Ambrosano GMB, Júnior CAL, Moraes ABA. Fatores determinantes do uso de chupeta entre criancas participantes de programa de incentivo ao aleitamento materno. Rev CEFAC. 2014;16(2):582-91.

16. Serra-Negra JM, Ramos-Jorge ML, Flores-Mendoza CE, Paiva SM, Pordeus IA Influence of psychosocial factors on the development of sleep bruxism among children. International Journal of Paediatric Dentistry. 2009;19(5):309-17.

17. Kwok KL, Poon G, Chau KW. Habitual snoring and sleep bruxism in a paediatric outpatient population in Hong Kong Singapore. Méd J. 2002;43(11):554-6.

18. Valera FCP, Travitzki LV, Mattar SE, Matsumoto MA, Elias AM, Anselmo-Lima WT. Muscular functional and orthodontic changes in pré school children with enlarged adenoids and tonsils. Int J Paediatr Otorhinolaryngol. 2003;67:761-70.

19. Cheifetz AT, Osganian SK, Allred EN, Needleman HL. Prevalence of bruxism and associated correlates in children as reported by parents. J Dent Child. 2005;72(2):63-73.

20. Sousa FRN, Giannina ST, Almeida RVD, Padilha WWN. O Aleitamento materno e sua relação com hábitos bucais deletérios e maloclusão dentária. Pesq Bras Odontoped Clín Integr. 2004;4(3):211-6.

21. Serra-Negra JMC, Pordeus IA, Rocha Jr JF. Estudo da associação entre aleitamento, hábitos bucais e maloclusões. Rev Odontol Univ São Paulo. 1997; 11(2):79-86

22. Amary ICM, Rossi LAF, Yumoto VA, Assencio-Ferreira VJ, Marchesan 10 Hábitos deletérios: alterações de oclusão. Rev CEFAC. 2002;4(2):123-6.

Article History: Submission Date : 09-04-2021; Revised Date : 28-04-2021; Acceptance Date : 24-05-2021.

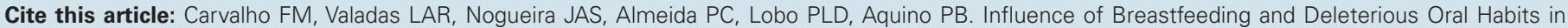
Malocclusions. J Young Pharm. 2021;13(2):172-7. 